\title{
The occurrence of Enterobacteriaceae in the well water of Nallur Divisional Secretariat area of Jaffna district, Sri Lanka.
}

\author{
A. Briyangari ${ }^{1,2}$ \\ ${ }^{1}$ Department of Pathobiology, Faculty of Veterinary Medicine and Animal Science, \\ University of Peradeniya, Sri Lanka. \\ ${ }^{2}$ Veterinary Surgeon's office, Nallur, Jaffna, Sri Lanka.
}

\begin{abstract}
The access for safe drinking water has become a challenge to human at present due to contamination with the different sources of pollution such as domestic waste, animal excreta and latrine leakage. Therefore, this study was carried out with the focus of determining the microbial quality of dug well water from a highly populated peri-urban area (Nallur Divisional Secretariat) of the Jaffna district in Sri Lanka. The water samples from 20 dug wells were collected from the study area and the information particularly the distance of well from the toilet septic tank, sanitary conditions of well and the surroundings were gathered. The total bacterial count was determined and different bacterial species were identified on Xylose Lysine Deoxycholate (XLD) agar.The t-test was performed to identify the factor/s that significantly influences the total bacterial count. A correlation analysis was performed between the distance of well from septic tank and bacterial count. Nine different bacterial species, that belong to the family Enterobacteriaceae, were identified; Klebsiella, Enterobacter, Escherichia, Salmonella, Shigella, Citrobacter, Yersinia, Serratia and Acinetobacter. Of the 72 bacterial isolates from 20 wells, 37 belong to the coliform group indicating recent faecal contamination. The total bacterial count has an inverse correlation with the distance of the toilet from the well $\left(R^{2}=0.506\right)$. Presence of pathogenic bacteria in the well water in the study is a great threat for human health and therefore, regular measures need to be taken to disinfect the water.
\end{abstract}

Keywords: Drinking water, Enterobacteriaceae, Faecal contamination, Jaffna district, Microbial contamination.

\section{INTRODUCTION}

The safe drinking water sources are shrinking globally due to various anthropogenic activities such as contamination of chemicals from industries and agriculture, and diseasecausing microorganisms (pathogens) from households and animal husbandry. According to the estimation of the World Health Organization (WHO), about 2.3 billion people globally do not have access to safe drinking water (WHO, 2017). Poor quality water is an important risk factor in the occurrence of waterborne illnesses; diarrhoea, cholera, schistosomiasis and gastrointestinal problems. Estimates in
North America reveal about 5 - 30\% of gastrointestinal diseases occur through water (Payment et al., 1997). Further, a recent study reported that around $63 \%$ of the children were infected with childhood diarrhoea in developing countries and approximately aetiological agent for $40 \%$ of the cases were unidentified (Ugboko $e t$ al., 2020). Although the drinking water stands impose the threshold level of physical, chemical and microbial parameters, they are not highly considered in the developing countries as people generally access untreated water from natural sources. In Sri Lanka, majority of the people consume untreated water from the natural sources apart from few urban
Corresponding author: briyangari.s@gmail.com

Received: 13.01.2021 
areas where treated water is provided by the National Water Supply and Drainage Board.

Jaffna district, which is one of the 25 administrative districts of Sri Lanka, is located in the far north of Sri Lanka in the Northern Province. In this region, water is naturally stored in the isolated caves and caverns of the underground limestone beds. This district highly depends on the groundwater for domestic and agricultural water use and retrieves the water from underground using dug wells. Approximately $80 \%$ of this groundwater is being used for agriculture, and $20 \%$ for domestic consumption in Jaffna (Panabokke and Perera, 2005). The rapid extension of the agriculture sector and increasing population in this region created a heavy competition for groundwater between major consumers. Alongside this, available domestic lands are fragmented due to the increasing population which results in close proximity houses. This increases the chance for contamination of well water with the faecal materials.

Human faecal material is generally considered to be a greater risk to human health as it is more likely to contain human enteric pathogens (Scott et al., 2003). Faecal contamination can be assessed by detecting the indicator organisms (faecal coliforms) in water. Presence of such bacteria could be taken as an indication of faecal contamination of the well water and the coliform count could be used to assess the severity of the contamination. The higher the level of indicator bacteria, the higher the degree of faecal contamination and the greater the risk of waterborne diseases (Pipes, 1982). A survey showed that globally 1.8 billion people access water sources which are contaminated with faecal matter (Bain et al., 2014). Major bacteria that involve in the causation of waterborne illnesses are enterotoxigenic Escherichia coli, possibly enteropathogenic Escherichia coli, Clostridium difficile, Salmonella spp.,
Shigella spp., Vibrio spp., Aeromonas spp., Campylobacter jejuni, and Yersinia spp. Excreta from human, animals and birds that can cause direct contamination of water or the proximity of pit latrines to the wells acts as the sources of contamination. The major concern of the waterborne illnesses is the enhanced risk, seen in a weaker population consisting young, old, pregnant and immunocompromised individuals (Leclerc et al., 2002).

The term Salmonellosis includes typhoid fever, paratyphoid fever and gastroenteritis caused by pathogenic species of Salmonella. It is one of the serious illnesses that end up in the death of the victim unless the treatment is initiated. Abdominal discomfort, diarrhoea, vomiting and weakness are some of the disease-related signs. The annual incidence of 17 billion cases was recorded worldwide due to Salmonellosis (Typhoid and Paratyphoid fever) (Kindhauser, 2003). In 2009, an outbreak of typhoid fever was reported in Pakistan, in which the involvement of well water was documented (Farooqui et al. 2009). Waterborne typhoid fever outbreaks have devastating public health implications. In Sri Lanka, 298 cases of enteric fever were reported in 2003. Of that, Jaffna district had the highest number of cases (107) (Ministry of Health, 2013). In recent years also, the highest number of cases were recorded in Jaffna district (Ministry of Health, 2017). This shows that the drinking water quality in Jaffna district is still under threat.

The recent knowledge about the microbial loading into the drinking water sources in Jaffna district is very limited. In a study, it was reported that out of $38 \%$ of sampling locations which were contaminated with Salmonella spp., six are being used for drinking purposes and $80 \%$ of the tested locations were beyond the drinking water quality standards (Mahagamage et al., 2019). Another study conducted in Kopay $\mathrm{MOH}$ area of Jaffna district stated that the 
surrounding environment of the wells was highly conductive for contamination and water in the study area was contaminated with faecal material (Arulnesan et al., 2015). However, there are no studies available for Nallur Divisional Secretariat of Jaffna district. Therefore, this study was aimed to determine the occurrence of bacterial contamination in the dug well water and possible factors influencing the microbial count in Nallur Divisional Secretariat of Jaffna district, Sri Lanka.

\section{MATERIALS AND METHODS}

\section{Study area and sample collection}

Thirunelvely, Kandarmadam, and Kalviyangadu of the Nallur Divisional
Secretariat of Jaffna district were selected as sampling regions (Figure 1). The period of this study was between May and July 2017. A total of 20 water samples were collected from the wells manually using a bucket-rope method in randomly selected houses. The water samples were collected in sterile $250 \mathrm{ml}$ plastic sampling bottles soon after drawing from the wells. Collected samples were transported with ice packs to the laboratory within 48 hours. At the time of sampling, the dimensions of the well (depth, diameter), distance of the well from the toilet, presence of aquatic life and floating materials within the well, surrounding environment of the well, history of waterborne diseases and the demography of the household owner were also determined.

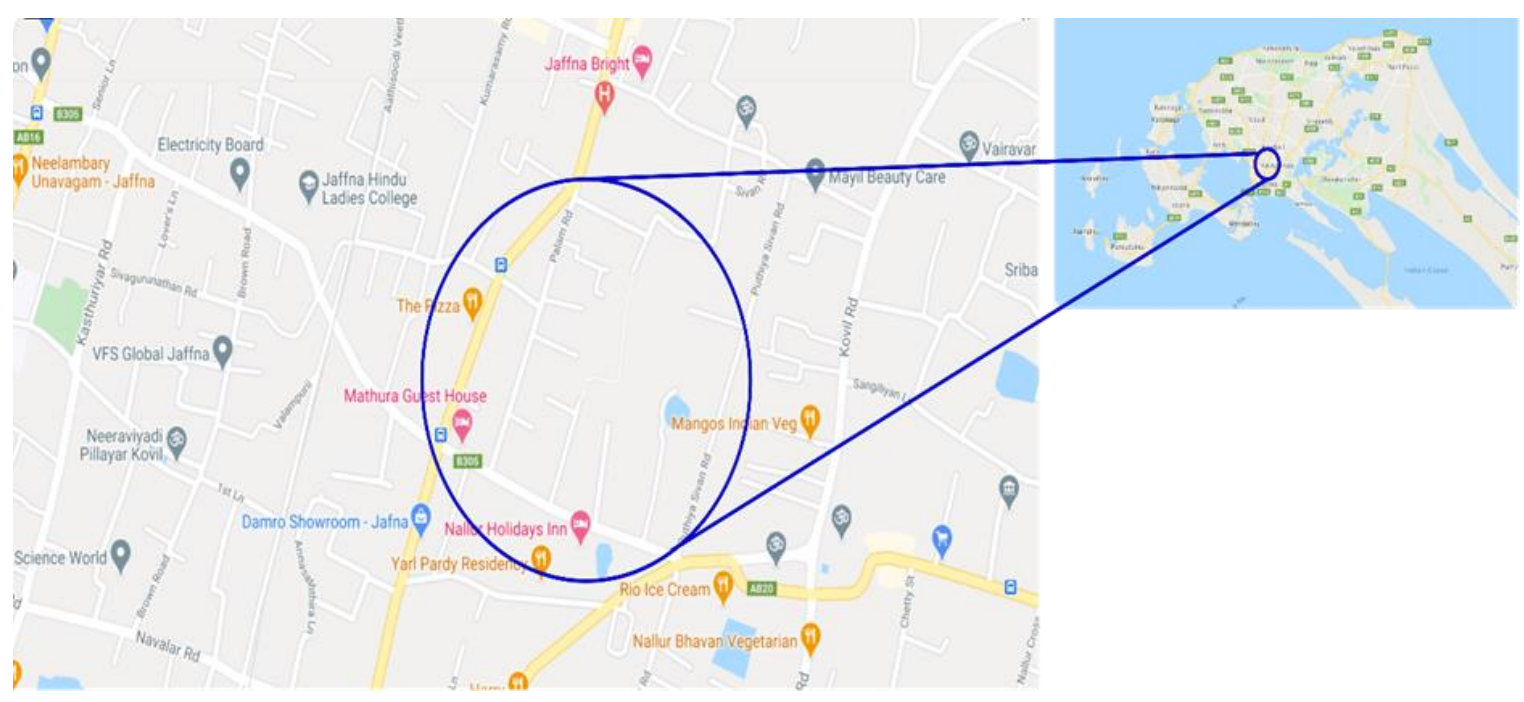

Figure 1. The sampling site of water samples from the wells.

\section{Isolation and identification of bacteria}

At the laboratory, $50 \mathrm{ml}$ of the water sample was centrifuged (Sigma 3-18KHS) at $3500 \mathrm{rpm}$ for 10 minutes and the supernatant was discarded until leaving 5 $\mathrm{ml}$ of sediment. The sediment was vortexed and $50 \mu \mathrm{l}$ of it was spread evenly on the XLD agar using a glass spreader. The plates were incubated at $37{ }^{\circ} \mathrm{C}$ for 24 hours and thereafter the colonies were - counted using a colony counter. After counting, a total of 72 different types of colonies (1 - 6 colonies per well) were selected and sub-cultured on XLD agar plate. The selected bacterial colonies were identified using phenotypic characters (Gram stain, oxidase, urease, citrate, Triple Sugar Iron test, motility and indole production) (Quinn et al., 2002). 


\section{Data analysis}

The data were analysed using Minitab 16 statistical software (Minitab, 2010). Pearson correlation analysis was performed between the total microbial count and distance of well from the toilet septic tank. The t-test was employed to identify the significance influence $(p<$ 0.05 ) of selected factors on the microbial count.

\section{RESULTS AND DISCUSSION}

\section{Species identification and total count of microbial colonies}

This study confirms the existence of both coliforms and other pathogenic bacteria in the collected well water samples. Out of the 72 isolates, more than half $(56.9 \%)$ belonged to Coliform group (E.coli, Klebsiella, Enterobacter, Citrobacter and
Serratia), which indicates the recent faecal contamination (Table 1). Eventhough there were harmless coliforms present in the group, the risk of acquiring waterborne diseases has been always there due to the presence of pathogenic bacteria. Indicator organism of choice for faecal contamination is E.coli and the count of this organism should be zero in $100 \mathrm{ml}$ of water (Standridge, 2008). However, 40\% of the wells sampled in this study were positive for E.coli, which emphasizes the unsuitability of water for human consumption without boiling or other water treatments. In a similar study conducted in Matara district, Sri Lanka, it was reported that $65 \%$ of wells were contaminated with faecal matter and it could be the main reason for the reported higher number of faecal-oral diseases in Matara district (Rathnayake and Rathnyake, 2008).

Table 1: Bacterial species identified from the total collected well water samples

\begin{tabular}{lcc}
\hline Bacterial species & Number of isolates & $\begin{array}{c}\text { Occurrence \% in total } \\
\text { samples }\end{array}$ \\
\hline Klebsiella spp & 13 & 65 \\
Escherichia coli & 8 & 40 \\
Salmonella spp. & 6 & 30 \\
Shigella spp. & 5 & 25 \\
Enterobacter spp. & 13 & 65 \\
Citrobacter spp. & 4 & 20 \\
Yersinia spp. & 1 & 5 \\
Serratia spp. & 3 & 15 \\
Acinetobacter spp. & 7 & 35 \\
Unidentified & 12 & 60 \\
\hline Total & 72 & - \\
\hline
\end{tabular}

Apart from these, $55.6 \%$ of the isolates have the pathogenic potential (Salmonella, Shigella, Klebsiella, Yersinia, Acinetobacter, and E.coli) (Figure 2). The coliforms including Klebsiella,
Enterobacter and E.coli were the predominant bacteria present in the well water. Further, Salmonella and Shigella were found in $30 \%$ and $25 \%$ of the wells, respectively (Table 1 ). The colony count 
ranged between $860-8820 \quad \mathrm{CFU} / \mathrm{ml}$ indicating all the selected wells had bacterial contamination.

Salmonella species were positive in the following well numbers; 4, 5, 14, 19 and 20 (Figure 3). Presence of pathogenic bacteria like Salmonella, Shigella, Klebsiella, E.coli, Yersinia and Acinetobacter is of high public health significance since they are related to the risk of causing diarrhoeal diseases (Ford et al., 1999).

In this study, $55.6 \%$ of pathogenic bacteria were isolated from the water samples (Table 1).

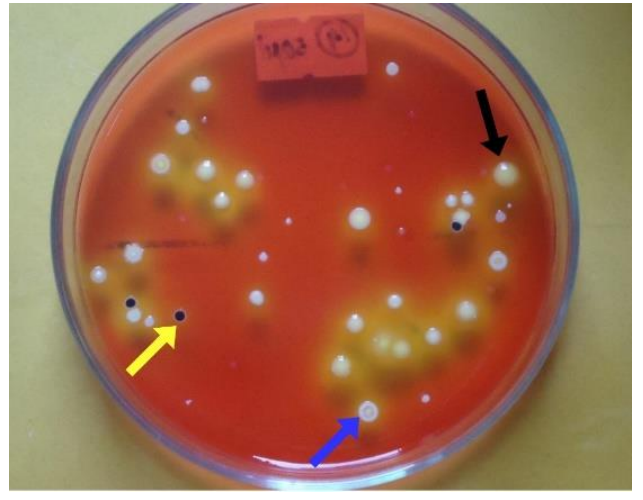

Figure 2: Different colonies identified on the XLD agar plate (The yellow arrow indicates a Salmonella colony, whereas blue and black arrows indicate Escherichia coli and Klebsiella colonies, respectively).

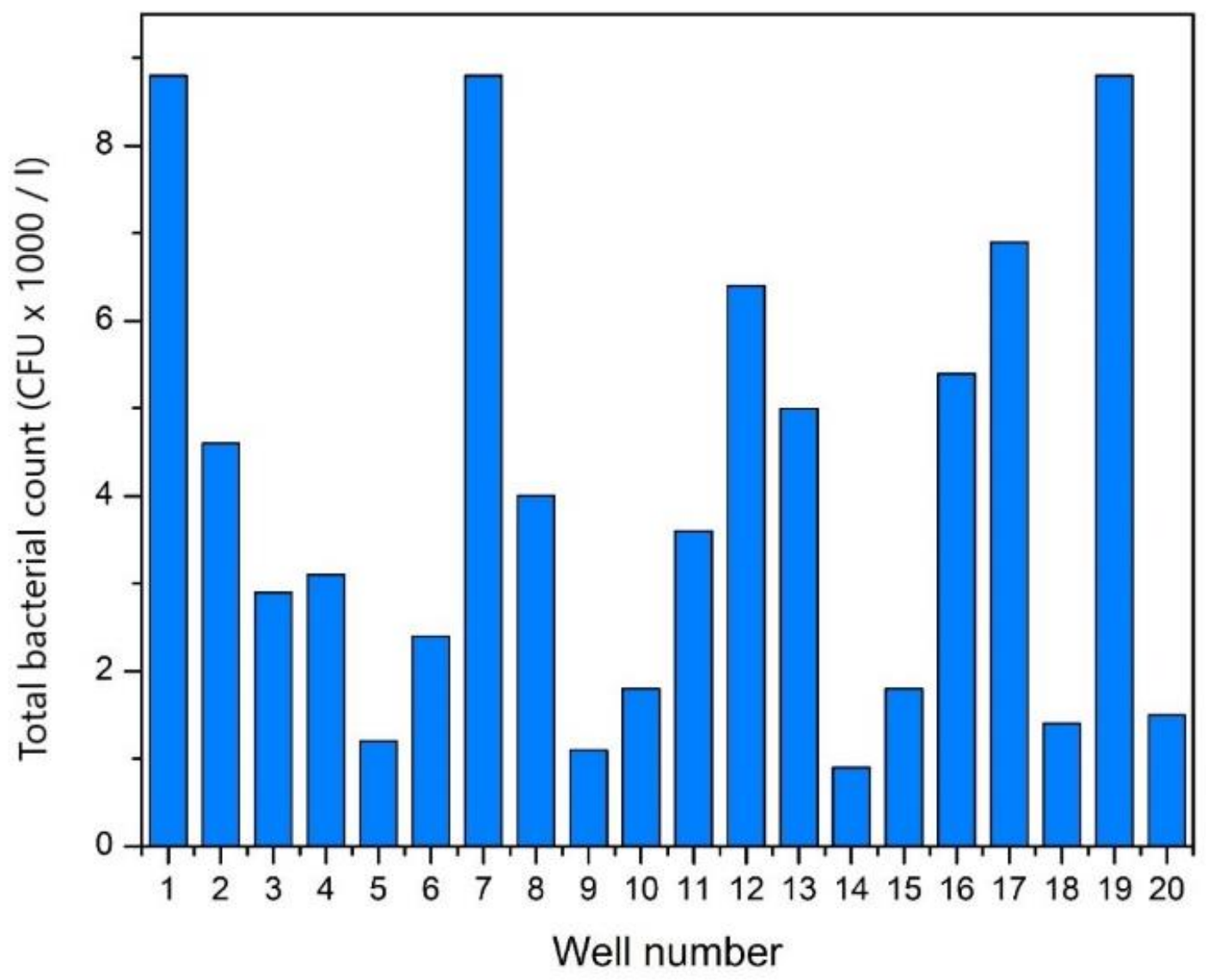

Figure 3: The total bacterial count in individual well. 


\section{The factors possibly involved in the contamination}

Table 2: Factors influence the bacterial count in well water

\begin{tabular}{|c|c|c|c|c|c|}
\hline \multirow[t]{2}{*}{ Variable } & & \multirow[t]{2}{*}{$\begin{array}{l}\text { No of } \\
\text { wells }\end{array}$} & \multicolumn{2}{|c|}{$\begin{array}{l}\text { Colony-forming units } \\
\text { (CFU/ml) }\end{array}$} & \multirow[t]{2}{*}{$P$-value } \\
\hline & & & Range & Mean \pm SE & \\
\hline \multirow{2}{*}{$\begin{array}{l}\text { Foreign substances on the } \\
\text { wall }\end{array}$} & Present & 15 & $860-8820$ & $4600 \pm 690$ & \multirow{2}{*}{0.938} \\
\hline & Absent & 5 & $920-3060$ & $3868 \pm 1467$ & \\
\hline \multirow{2}{*}{ Watering method } & Pulley & 11 & $860-8740$ & $4035 \pm 822$ & \multirow[t]{2}{*}{0.906} \\
\hline & Motor & 9 & $1220-8820$ & $3887 \pm 977$ & \\
\hline \multirow{2}{*}{$\begin{array}{l}\text { Holes on the wall of the } \\
\text { well }\end{array}$} & Present & 4 & $860-8740$ & $4315 \pm 1674$ & \multirow[t]{2}{*}{0.822} \\
\hline & Absent & 16 & $920-8820$ & $3881 \pm 673$ & \\
\hline \multirow{2}{*}{$\begin{array}{l}\text { Birds' faeces near the } \\
\text { well }\end{array}$} & Present & 7 & $860-8740$ & $4917 \pm 1103$ & \multirow[t]{2}{*}{0.293} \\
\hline & Absent & 13 & $920-8820$ & $3457 \pm 726$ & \\
\hline \multirow{2}{*}{$\begin{array}{l}\text { Birds on the trees around } \\
\text { the well }\end{array}$} & Present & 16 & $860-8740$ & $4374 \pm 709$ & \multirow[t]{2}{*}{0.115} \\
\hline & Absent & 4 & $1220-8820$ & $2345 \pm 876$ & \\
\hline \multirow{2}{*}{$\begin{array}{l}\text { Foreign substances on } \\
\text { water }\end{array}$} & Present & 15 & $1160-8740$ & $4366 \pm 671$ & \multirow[t]{2}{*}{$0.027 *$} \\
\hline & Absent & 5 & $860-8820$ & $1713 \pm 677$ & \\
\hline \multirow{2}{*}{$\begin{array}{l}\text { Toilet distance from the } \\
\text { well }\end{array}$} & $<10 \mathrm{~m}$ & 7 & $1800-8820$ & $6663 \pm 963$ & \multirow{2}{*}{$0.004 *$} \\
\hline & $>10 \mathrm{~m}$ & 13 & $860-5020$ & $2517 \pm 408$ & \\
\hline \multirow{2}{*}{ Occupation of the owner } & Gov & 9 & $860-4740$ & $2067 \pm 445$ & \multirow{2}{*}{$0.002 *$} \\
\hline & NGO & 11 & $1700-8820$ & $5527 \pm 796$ & \\
\hline \multirow[t]{3}{*}{ Chlorination interval } & 0-4 weeks & 9 & $860-6480$ & $2722 \pm 1822$ & \multirow{3}{*}{0.174} \\
\hline & 4-8 weeks & 3 & $1220-6880$ & $4440 \pm 2910$ & \\
\hline & $>8$ weeks & 8 & $1160-8820$ & $5193 \pm 32$ & \\
\hline
\end{tabular}

$\mathrm{SE}=$ Standard error, Gov = Government organization, NGO = Non-government organization, * Significant difference at 0.05 probability level.

The total bacterial count was significantly influenced by the presence of foreign substances on water (coconuts, coconut leaves, coconut husks, coconut fluorescence, other leaves and shopping bags), toilet distance from the well and occupation of the well owner or tenant
(Table 2). The occupation and the educational status of an individual are interconnected. Therefore, the negative correlation for bacterial count with occupation could be ascribed to the awareness on sanitary measures of maintaining clean well water. The total 
bacterial count was high when the distance between the toilet pit and the well was less than $10 \mathrm{~m}$ (Table 2; Figure 4). Increase in chlorination frequency decreased the bacterial count but this was not significant (Table 2).

The depth of the wells, well diameter, presence of aquatic life, presence of the birds' faecal matter in the surrounding of the well were also analysed to explore the bacterial contamination related to the above factors. However, the results showed no correlation between the bacterial count and the aforementioned factors.

\section{The correlation between total bacterial count and distance between toilet and well}

The correlation between total bacterial count and distance from the toilet was moderate $\left(R^{2}=0.51\right)$ (Figure 4). Similar observation was reported, in which faecal coliform, nitrate and phosphate concentration were negatively correlated to the distance from the toilet (Arnade, 1999).

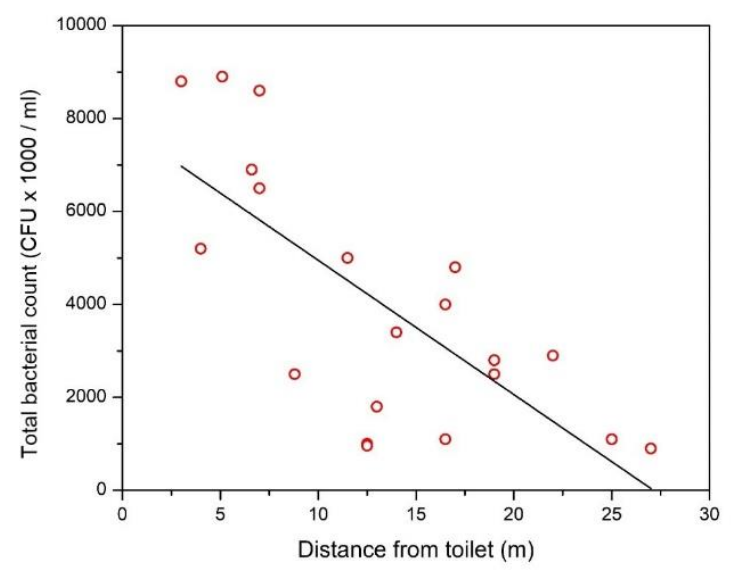

Figure 4: The correlation between the total bacterial count and distance from the toilet pit.

The severity of contamination is seasonal and the possibility is high in the rainy season (Singh et al., 2019) as the well water gets contaminated by the seepage flow of water from the septic tanks (Graham et al, 2013). In a flooding condition due to heavy rainfall, both wells and septic tanks can be in direct hydraulic connection if both are located nearby. Therefore, the distance and depth of the well from the septic tank of toilet need to be put up beyond an appropriate distance before planning to build houses. However, increasing population decreases the land size that makes it difficult to maintain the sufficient distance between the septic tank and well.

According to the guidelines of urban development authority of Sri Lanka, the distance between the septic tank and well should not be less than $15 \mathrm{~m}$ (Urban development authority, 1986). However, in this study, $60 \%$ of the wells studied were not complied with the standards. Similarly the study conducted in Gampaha, Sri Lanka also revealed that over $68 \%$ of the toilets were built within $15 \mathrm{~m}$ peripheral from the well (Bandara and Najim, 2013). The majority of the people are ignorant of the well water contamination with faecal material and other chemical sources. Also general public have lack of awareness on the transmission and prevention of waterborne diseases (Arulnesan et al., 2015).

In a developing country like Sri Lanka, it is very difficult for the government bodies to monitor the changes of the water in the individual wells in a periodical manner and there have been no support for the regular inspection process. Therefore, it is the responsibility of each well owner to maintain the sanitary condition to safeguard them from waterborne diseases.

Considering the potential risks of contaminated water, remedial measures should be initiated. Chlorination can be used to reduce the disease burden due to contaminated water, since it is one of the simplest, inexpensive, commonly used methods with the lowest operating cost and the longest history for continuous disinfection process (Burch et al., 1998). The success of the water treatment 
depends on the amount of chlorine used, the contact time of chlorine and frequency of chlorination. The amount of chlorine to be used should be decided based on the volume of the well. The ideal dosage is $4 \mathrm{mg} / \mathrm{l}$ or $4 \mathrm{ppm}$ for safe use (EPA, 2013). Boiling the water also a cheap option to kill a significant amount of microbes received from faecal contamination (Clasen et al., 2008).

\section{CONCLUSION}

This study found that all the dug wells under investigation were contaminated with different bacterial species. The total bacterial count in the water samples ranged from 860 - $8820 \mathrm{CFU} / \mathrm{ml}$ indicates a severe degree of contamination. The finding of coliforms strongly suggests the faecal contamination. Further, the detection of pathogenic bacteria (i.e: Salmonella and Shigella) indicates the risk of water borne infections. The bacterial count showed an inverse correlation with the distance to toilet pit from well and educational status of the owners while a positive correlation was found with the presence of foreign materials. These findings implicit the study area was at high health risk. Therefore, remedial measures are strongly recommended before direct human consumption of water from these sources.

\section{Acknowledgements}

The author acknowledges the technical staff of Centre for Aquatic Disease Diagnosis and Research (CADDAR), Peradeniya, Sri Lanka for their assistance for this research. Further, author extends gratitude for the well owners who supported this study.

Conflicts of Interests: The author declares that there are no conflicts of interests.

\section{REFERENCES}

Arnade, L. J. (1999). Seasonal correlation of well contamination and septic tank distance. Groundwater, 37(6): 920-923.

Arulnesan, C., Kamsan, S., Rajeshkannan, N., Sivapalan, K., and Murugananthan, K. (2015). Microbial contamination of public drinking water sources and associated factors in Kopay Medical Officer of Health area Jaffna, Sri Lanka. Sri Lankan Journal of Infectious Diseases 5 (2):64-72.

Bain, R., Cronk, R., Hossain, R., Bonjour, S., Onda, K., Wright, J., Yang, H., Slaymaker, T., Hunter, P., Prüss-Ustün, A. and Bartram, J. (2014). Global assessment of exposure to faecal contamination through drinking water based on a systematic review. Tropical Medicine \& International Health 19(8):917-927.

Bandara, H., and Najim, M. (2013). Compliance with standards and immerging issues of household sewage disposal systems in Gampaha Municipality Area in Western Sri Lanka. Journal of Environmental Professionals Sri Lanka 2(2): 1-12.

Burch, J. D., and Thomas, K. E. (1998). Water disinfection for developing countries and potential for solar thermal pasteurization. Solar Energy 64(1-3): 8797.

Clasen, T., McLaughlin, C., Nayaar, N., Boisson, S., Gupta, R., Desai, D., and Shah, N. (2008). Microbiological effectiveness and cost of disinfecting water by boiling in semi-urban India. The American journal of tropical medicine and hygiene 79(3): 407-413.

EPA. (2013). Basic Information about Disinfectant in Drinking Water: Chloramine, Chlorine and Chlorine Dioxide. 
Farooqui, A., Khan, A., and Kazmi, S. U. (2009). Investigation of a community outbreak of typhoid fever associated with drinking water. BMC public health 9(1):16.

Ford, T. E. (1999). Microbiological safety of drinking water: United States and global perspectives. Environmental Health Perspectives 107(suppl 1): 191-206.

Graham, J. P., and Polizzotto, M. L. (2013). Pit latrines and their impacts on groundwater quality: a systematic review. Environmental health perspectives 121(5): 521-530.

Kindhauser, M. (2003). Global defence against the infectious disease threat. Communicable Diseases 2002. World Health Organization, Geneva, 1-231.

Leclerc, H., Schwartzbrod, L., and DeiCas, E. (2002). Microbial agents associated with waterborne diseases. Critical reviews in microbiology 28(4): 371-409.

Mahagamage, M., Manage, P. S., and Manage, P. M. (2019). Water quality and microbial contamination status of groundwater in Jaffna Peninsula, Sri Lanka. Journal of Water and Land Development 40(1): 3-12.

Ministry of Health, S. L. (2013). Annual Epidemiological Bulletin, Second Quarter. Colombo, Sri Lanka.

Ministry of Health, S. L. (2017). Annual Epidemiological Bulletin, Second Quarter. Colombo, Sri Lanka.

Minitab, I. (2010). Minitab 16 statistical software. URL:[Computer software]. State College, PA: Minitab, Inc.(www. minitab. com).

World Health Organization (2017). Safely managed drinking water: thematic report on drinking water 2017.

Panabokke, C., and Perera, A. (2005). Groundwater resources of Sri Lanka.
Water Resources Board, Colombo, Sri Lanka, 28.

Payment, P., Siemiatycki, J., Richardson, L., Renaud, G., Franco, E., and Prevost, M. (1997). A prospective epidemiological study of gastrointestinal health effects due to the consumption of drinking water. International Journal of Environmental Health Research 7(1): 5-31.

Pipes, W. O. (1982). Bacterial indicators of pollution: CRC.

Quinn, P., Markey, B. K., Carter, M., Donnelly, W., and Leonard, F. (2002). Veterinary microbiology and microbial disease: Blackwell science.

Rathnayake, T., and Rathnyake, R. (2008). How safe is our drinking water. Journal of the Ruhunu Clinical Society 15: 17-19.

Scott, T.M., Parveen, S., Portier, K.M., Rose, J.B., Tamplin, M.L., Farrah, S.R., Koo, A. and Lukasik, J. (2003). Geographical variation in ribotype profiles of Escherichia coli isolates from humans, swine, poultry, beef, and dairy cattle in Florida. Applied and Environmental Microbiology 69(2): 1089-1092.

Singh, A.K., Das, S., Singh, S., Pradhan, N., Gajamer, V.R., Kumar, S., Lepcha, Y.D. and Tiwari, H.K., (2019). Physicochemical parameters and alarming coliform count of the potable water of Eastern Himalayan state Sikkim: An indication of severe faecal contamination and immediate health risk. Frontiers in public health 7: 174.

Standridge, J. (2008). E. coli as a public health indicator of drinking water quality. Journal-American Water Works Association 100(2): 65-75.

Ugboko, H. U., Nwinyi, O. C., Oranusi, S. U., and Oyewale, J. O. (2020). Childhood diarrhoeal diseases in developing countries. Heliyon 6(4): e03690.

Urban development authority. (1986). Urban development authority planning and building regulation. 